\title{
Analysis of carrying capacity and land suitability in Kenjeran Coastal Area, Bulak Sub Regency, Surabaya City, East Java
}

\author{
Zulqi Fahreza Akbar *, Rudianto*, Andik Isdianto* \\ Study Program of Marine Sciences, Faculty of Fisheries and Marine Sciences, University \\ of Brawijaya
}

\begin{tabular}{l}
\hline \hline INFO ARTIKEL \\
\hline Riwayat Artikel: \\
Dikirim: $30-11-2018$ \\
Disetujui: $2-1-2019$ \\
Diterbitkan: $31-1-2019$
\end{tabular}

\section{Keywords:}

coastal area; land transfer function; remote sensing; farmer; shrimp ponds;

\begin{abstract}
ABSTRAK
Abstract: Beach tourism is an activity that spends time while feeling the beauty of the atmosphere around the beach. The city of Surabaya has one of the most attractive natural tourist destinations and is located on the Kenjeran beach in the eastern part of Surabaya. This beach tourism activity can cause water pollution due to waste from tourism activities and can cause damage to coastal ecosystems. The purpose of this study is to determine the value of the Land Suitability Index and the value of carrying capacity of the land as a beach tourism. The method used in this study was to measure water quality, measure grain size of sediments, observe criteria for objects and tourist attractions, and conduct interviews. The results of this study indicate that of the 4.3 hectares of the Kenjeran Beach Conformity Index value for the coastal tourism category a score of $47.8 \%$ was obtained in the S3 category. This category includes having more limiting factors to fulfill. These factors will have an impact on reducing tourist satisfaction for tourism. This Kenjeran Beach has a maximum value with regional carrying capacity that can accommodate 2,580 people per day for 9 hours
\end{abstract}

\begin{abstract}
Abstrak: Wisata pantai adalah kegiatan yang menghabiskan waktu sambil merasakan keindahan suasana di sekitar pantai. Kota Surabaya memiliki salah satu tujuan wisata alam yang paling menarik dan terletak di pantai Kenjeran di bagian timur Surabaya. Kegiatan wisata pantai ini dapat menyebabkan pencemaran air karena limbah dari kegiatan pariwisata dan dapat menyebabkan kerusakan ekosistem pesisir. Tujuan dari penelitian ini adalah untuk menentukan nilai Indeks Kesesuaian Lahan dan nilai daya dukung lahan sebagai wisata pantai. Metode yang digunakan dalam penelitian ini adalah mengukur kualitas air, mengukur ukuran butiran sedimen, mengamati kriteria untuk objek dan tempat wisata, dan melakukan wawancara. Hasil penelitian ini menunjukkan bahwa dari 4,3 hektar nilai Indeks Kesesuaian Pantai Kenjeran untuk kategori pariwisata pantai diperoleh skor $47,8 \%$ dalam kategori S3. Kategori ini termasuk memiliki faktor pembatas yang lebih banyak untuk dipenuhi. Faktor-faktor ini akan berdampak pada pengurangan kepuasan wisatawan untuk pariwisata. Pantai Kenjeran ini memiliki nilai maksimum dengan daya dukung regional yang dapat menampung 2.580 orang per hari selama 9 jam.
\end{abstract}


Jurnal Pendidikan Geografi:

Kajian, Teori, dan Praktik dalam Bidang Pendidikan dan Ilmu Geografi

Tahun 24, Nomor 1, Jan 2019, Hal 52-66

\author{
Address Correspondence: \\ Rudianto \\ Study program of Marine Science \\ Faculty of Fisheries and Marine Science \\ Address: Jalan Veteran Malang, 65145 \\ E-mail: rudiantoita@gmail.com
}

\title{
INTRODUCTION
}

The tourism sector is one of the mainstays in improving the Indonesian economy, both as economic activities that can generate employment and increase people's income. The tourism sector is relied on to increase state revenues, regional income, and foreign exchange. Thus, the tourism sector needs to be well planned, systematic and comprehensive both locally, regionally and even nationally while maintaining sustainable development (Abdillah, 2016). According to data recorded at the Kenjeran Beach Service Technical Implementation Unit, the number of tourists in 2012 was 399,588 people and increased to 529,588 people in 2017. The increase in the number of tourists is predicted to continue to increase annually. This is because the urban population's needs for the tourism sector are increasing.

The development of tourism areas in urban areas is suspected of causing pollution caused by the garbage disposal of the surrounding communities as well as by large, medium, medium and small industrial wastes that dispose of their waste to the coastal ocean without wastewater treatment. Pollution of the coastal and marine environment occurs. This will result in the disruption of the tourism area. Besides that, damage to coastal ecosystems also occurs and results in the service of coastal ecosystems to their environment will not be optimal. Coastal and marine pollution and service of coastal ecosystems will disrupt the number of future tourists. If the conditions of the coastal and marine environment continue to occur, the attractiveness and intrinsic value of the environment will be lost. The impact that occurred was a significant decrease in the number of tourists so that the government, investors and local communities could no longer benefit from the tourism sector (Lumaksonoet dkk.,2012 in Wijayanto dkk., 2013). The problem that occurs in the research area is pollution and the increasing density of residents around Kenjeran. Meanwhile, the potential of Kenjeran beach can be developed into an ecotourism area. 


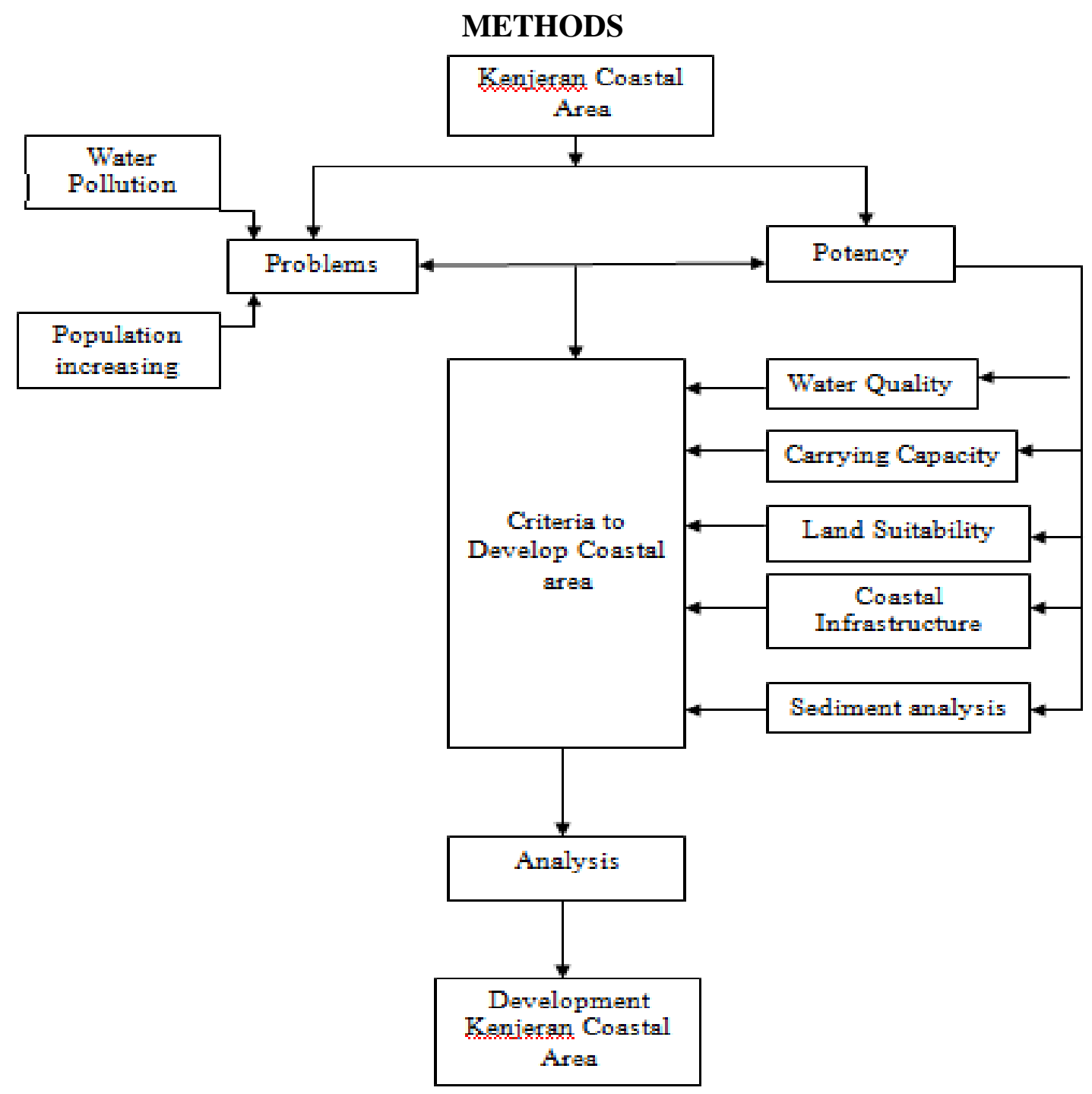

Fig 1. Flow of Research Methods

This research was conducted on March 24, 2018 - April 24, 2018, in the old Kenjeran Beach, Kenjeran Village, Bulak District, Surabaya City. The study was conducted at three (3) stations (see picture 1) on the old Kenjeran Beach. Station selection is carried out in three (3) locations using general and objective survey and observation methods, as well as seeing pollution phenomena and measuring water quality conditions. Station 1 is at latitude coordinates $-7.237620^{\circ}$ and longitude $112.796460^{\circ}$, station 2 is at the coordinate point $7.236907^{\circ}$ and longitude $112.796199^{\circ}$, and at station 3 is at coordinate point latitude$7.236226^{\circ}$ and longitude $112.795950^{\circ}$. Broadly speaking this research is divided into two stages of activity: The first stage is the stage before fieldwork. This stage includes field observations by determining the types of primary data and secondary data. The type of primary data is data obtained directly through surveys, observations and direct interviews with local community as many as 30 residents, the number of visitors is as many as 20 respondents and respondents from the manager of Kenjeran beach.

The phase of fieldwork includes data collection carried out by surveys, field observations, and literature studies. Retrieving data on water quality is done by measuring 
Jurnal Pendidikan Geografi:

Kajian, Teori, dan Praktik dalam Bidang Pendidikan dan Ilmu Geografi

Tahun 24, Nomor 1, Jan 2019, Hal 52-66

water quality in accordance with the conditions at the time. Water quality data collection is determined by three observation stations that have different characteristics and conditions. Measurement of water quality parameters is carried out when the condition of the water is tiding, namely at $14.00 \mathrm{pm}$. After taking water quality data, it is adjusted to the quality standard for tourism activities provided by the Decree of the Minister of Environment No. 51 of 2004. After measuring water quality, a statistical analysis was performed using a comparative descriptive method. Comparative analysis (t-test) is done with the aim of analyzing a relationship between variables 1 and 2 using water quality parameters (Nalim, 2015). Relationship of water quality parameters: station 1 with station 2 , station 1 with station 3, and station 2 with station 3 .

Size of sediment granules According to Indarto (1997) in Purnawan dkk (2012) said that sediment sampling is carried out by means of dredging using fog with a sediment depth of $15 \mathrm{~cm}$ as much as 200 grams with a distance of 30 meters from the coastline (boundary line between land and water sea). The distance is the maximum distance for visitors who play water and swim activities so that they can be said to represent sediment data for each station.

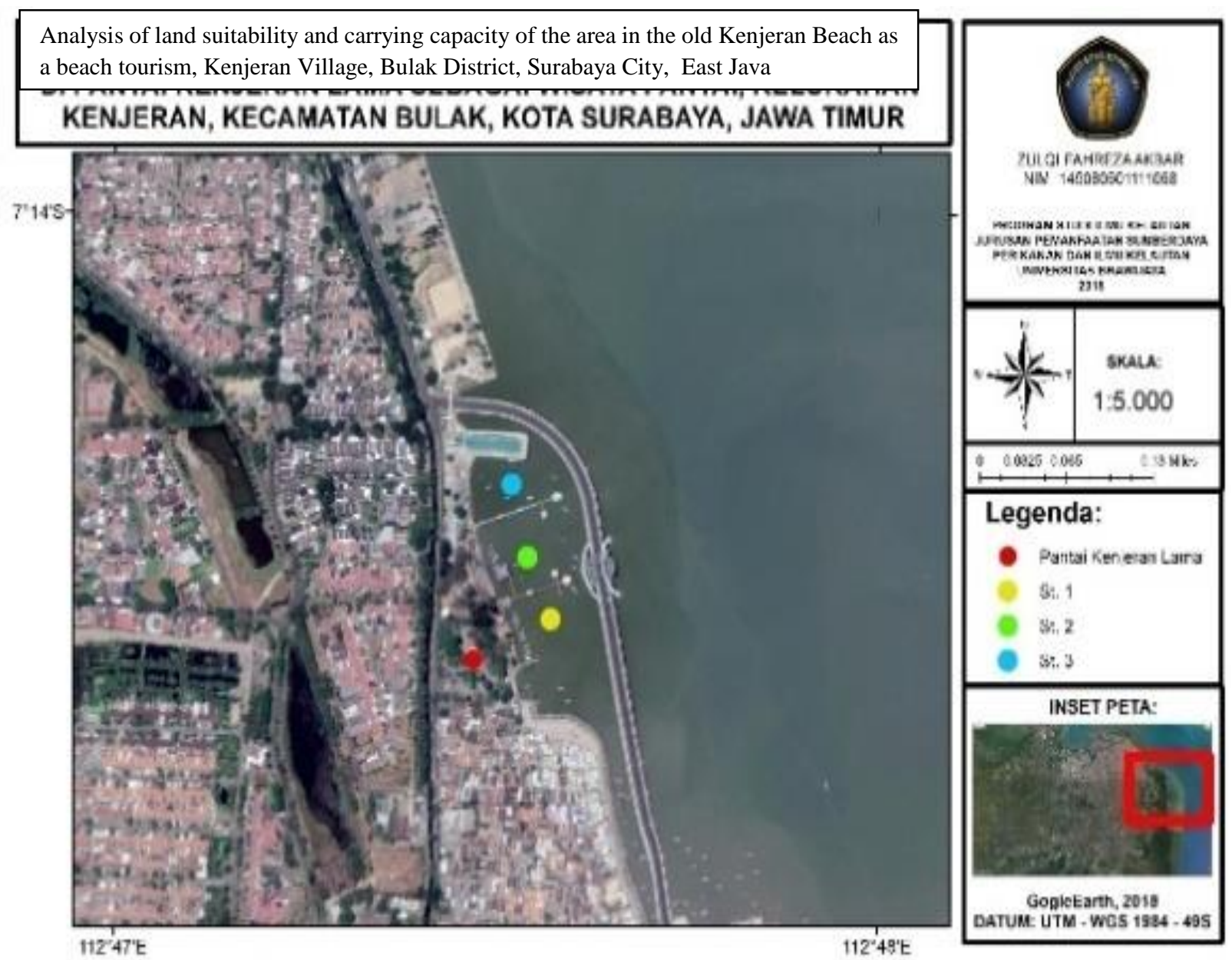

Fig 2. Research Location

According to Yulianda (2007) in Sukandar dkk (2017), the analysis of the suitability of coastal tourism land was carried out in order to determine the suitability of land in the tourist area. The land suitability formula used for coastal tourism is: 
Jurnal Pendidikan Geografi:

Kajian, Teori, dan Praktik dalam Bidang Pendidikan dan Ilmu Geografi

Tahun 24, Nomor 1, Jan 2019, Hal 52-66

$\mathrm{IKW}=\Sigma[\mathrm{Ni} / \mathrm{N} \max ] \mathrm{X} 100 \%$

Remarks:

IKW: Tourism Compliance Index

$\mathrm{Ni}$ : The i-parameter value (weight $\mathrm{x}$ score)

Nmax: The maximum value of a tourist category

Land suitability analysis is calculated with several parameters which are one of the supporting factors in the activities carried out in the area provided. The classes are divided into 4 land suitability categories namely:

$\mathrm{S} 1=$ Very Appropriate, $\mathrm{IKW}=80-100 \%$

$\mathrm{S} 2=$ Fairly Corresponding, IKW $=50-80 \%$

$\mathrm{S} 3=$ According to Conditional, IKW $=17-50 \%$

$\mathrm{N}=$ Not Corresponding, IKW $=<17 \%$

According to Yulianda (2007) in Sukandar dkk (2017) said that the carrying capacity of the region is the maximum value of the number of visitors physically can be accommodated in the area that has been provided for a certain time so as not to cause a disturbance to humans and nature. The determination of regional carrying capacity (DDK) with the formula is:

$\mathrm{DDK}=\mathrm{K} \times \mathrm{Lp} / \mathrm{Lt} \times \mathrm{Wt} / \mathrm{Wp}$

Information:

DDK = Regional support (people).

$\mathrm{K}=$ Ecological potential supporting unit area (people);

$\mathrm{Lp}=$ Area $(\mathrm{m} 2)$ or length of the area $(\mathrm{m})$ that can be utilized;

$\mathrm{Lt}=$ Unit area that can be used for certain activities $\left(\mathrm{m}^{2}\right)$ or $\mathrm{m}$

$\mathrm{Wt}=$ Time provided by the area for tourism activities in one day (hours)

$\mathrm{Wp}=$ Time spent by visitors for any particular activity (hours)

According to Jainuri dkk (2014) said that the analysis of the potential and attractiveness of tourist objects can be analyzed using Analysis of the Object Operation Area and Nature Tourism Attraction.

\section{Water Quality Measurement Results \\ RESULTS AND DISCUSSION}

Water quality, in general, is one of the variables that indicate whether or not waters for coastal tourism activities are good or not. The results of measurements of physical and chemical parameters in the old Kenjeran Beach are seen in table 1 below. 
Jurnal Pendidikan Geografi:

Kajian, Teori, dan Praktik dalam Bidang Pendidikan dan Ilmu Geografi

Tahun 24, Nomor 1, Jan 2019, Hal 52-66

Table 1. Water Quality Measurement Results

\begin{tabular}{ccccccc}
\hline No. & Item & Station 1 & Station 2 & Station 3 & Average & Standards \\
\hline 1. & Depth $($ meter $)$ & 0,82 & 0,98 & 0,71 & 0,90 & Nothing \\
\hline 2. & Temperature $\left({ }^{\mathrm{O}} \mathrm{C}\right)$ & 31,14 & 31,8 & 31,21 & 31,51 & Natural \\
\hline 3. & Salinity $(\mathbf{\% o})$ & 23,84 & 25,18 & 25,54 & 24,87 & Natural \\
\hline 4. & $\mathrm{pH}$ & 7,76 & 7,98 & 7,96 & 7,90 & $7-8,5$ \\
\hline 5. & DO $(\mathrm{Mg} / \mathrm{l})$ & 3,67 & 4,47 & 4,56 & 4,23 & $>5 \mathrm{mg} / 1$ \\
\hline 6. & Brightness \%(cm) & 13,5 & 17,5 & 14,5 & 15,17 & $>6 \mathrm{~meter}$ \\
\hline 7. & Nitrate $(\mathrm{mg} / \mathrm{l})$ & 0,25 & 0,21 & 0,15 & 0,20 & $0,06 \mathrm{Mg} / 1$ \\
\hline 8. & Nitrat $(\mathrm{mg} / \mathrm{l})$ & 0,16 & 0,08 & 0,08 & 0,10 & $0,08 \mathrm{Mg} / 1$ \\
\hline 9. & Garbage & There is & There is & There is & There is & Nothing \\
\hline 10. & Conclusion & $\begin{array}{c}\text { Not } \\
\text { appropriate }\end{array}$ & $\begin{array}{c}\text { Not } \\
\text { appropriate }\end{array}$ & $\begin{array}{c}\text { Not } \\
\text { appropriate }\end{array}$ & $\begin{array}{c}\text { Not } \\
\text { appropriate }\end{array}$ & $\begin{array}{c}\text { Not } \\
\text { appropriate }\end{array}$ \\
\hline
\end{tabular}

The results of the measurement of water quality are concluded that at station 1, station 2 and station 3 the results are not suitable for coastal tourism activities. This is because the parameters of depth, temperature, salinity, $\mathrm{pH}$, Do are still classified according to quality standards. The following is an explanation of the water parameters as stated below.

\section{Water Depth}

The results of measurements on the old Kenjeran Beach using AAQ 1183 tools has obtained an average depth of 0.90 meters. The highest depth occurs at station 2 with a depth of 0.98 meters. This happens because the location is a path for fishing boats and a stage pier. The lowest depth occurs at station 3 . This occurs because when the location is squeezed by fountains and docks and not the path for fishing boats. The ideal depth is an influence for tourists who want to do recreational activities to play water and swim, especially for beginners or those who cannot swim.

\section{Water Temperature}

The measurement results in the old Kenjeran Beach using AAQ 1183 tools obtained the value of temperature at each station ranged from 31.080 degrees $C-31.210$ degrees $C$. Water temperature has a relationship with the entry of the intensity of light entering water. According to Souhoka and Patty, (2013) said that temperatures commonly found in Indonesian sea waters ranged from 270 degrees C - 320 degrees $\mathrm{C}$. While according to water quality standards, the water temperature adjusted to the temperature conditions around the old Kenjeran Beach.

\section{Salinity}

The results of measurements carried out in the old Kenjeran Beach using AAQ 1183 tools, the results obtained based on table 12 can be known the salinity value of the three stations with time is not much different, ranging from $23.89 \%-25.54 \%$. This is because around the old Kenjeran Beach there are rivers that originate from settlements, rainfall, and evaporation. According to Arief (1984) said that fresh water originating from the river flow has a low salinity value which is generally less than $3 \%$, while the salinity of seawater is above $33 \%$. According to water quality standards, water salinity adjusts to conditions around the old Kenjeran Beach. According to Nontji (2008) in Guntur dkk (2017), the distribution of salinity that occurs in the Madura Strait waters has varying distribution values, namely 26-30 27 with an average of $27.8 \%$ which tends to be classified as low compared to the sea off Indonesia which is $33-35 \%$. 
Jurnal Pendidikan Geografi:

Kajian, Teori, dan Praktik dalam Bidang Pendidikan dan Ilmu Geografi

Tahun 24, Nomor 1, Jan 2019, Hal 52-66

\section{pH}

The results of measurements at the old Kenjeran Beach using AAQ 1183 were obtained for $\mathrm{pH}$ values at all three stations, namely between $7.76-7.98$. This value shows that at each station produces a value that is in accordance with the quality standards of water quality. According to the quality standard, the $\mathrm{pH}$ value ranges from $7-8.5$. The results of these measurements are obtained according to the quality standard. Susana (2009) says that the value of acidity $(\mathrm{pH})$ and oxygen concentration can change at any time. This is due to the abundance of chemical compounds that are either pollutants or non-pollutants. Changes in $\mathrm{pH}$ values dramatically affect aquatic biota. In general, the normal $\mathrm{pH}$ value is 7-8.5.

\section{Dissolved Oxygen}

Dissolved Oxygen is the amount of oxygen dissolved in a water, which comes from photosynthesis or diffusion between air and water. The results of measurements on the old Kenjeran Beach using AAQ 1183 tools obtained DO values at stations 1, 2 and 3 having DO values that are in accordance with the quality standard namely $>5$. According to Minister of Living Environment Decree No. 51 of 2004 concerning quality standards for water quality can be said that the limit of dissolved oxygen is $<5 \mathrm{mg}$ per liter, while the results obtained in measurements of Do in stations 1 and 2 are categorized accordingly, but at station 3 it is categorized as inappropriate. According to Abida (2008) in Guntur dkk (2017) said dissolved oxygen (Do) around the waters of the Madura Strait has a Do value that varies, generally, the high value of Do is in the high seas and the value of Do will decrease if it is towards the coast.

\section{Brightness}

Water brightness is a level of transparency that can be measured using a secchi disk tool. Water brightness is closely related to comfort for tourists, especially for tourists who want to do swimming activities because it affects the vision in the water. The measurement results from the three stations obtained a brightness value of $13.5 \mathrm{~cm}-17.5 \mathrm{~cm}$ with a quality standard $>6$ meters. It can be said that the water brightness parameters are not in accordance with the quality standards for marine tourism. Guntur dkk, (2017) stated that the small brightness value is caused by the amount of dissolved or suspended substances (substances not dissolved and not settling directly) on the waters of the East Coast Coast of Surabaya City.

\section{Nitrate $\left(\mathrm{NO}_{2}^{-}\right)$}

Nitratee is a matter that greatly influences waters because of the association with waste in the waters, especially the coast which is a river discharge originating from land. Determination of Nitratee Content was carried out using a spectrophotometric device. Nitratee in waters is also very related to the convenience of tourism, especially for tourists who do swimming activities because the level of pollution of waters is seen from the Nitratee levels that come from household and industrial waste that flows from the river to the beach. The measurement results of the three stations obtained values of $0.15 \mathrm{mg} / 1-0.25 \mathrm{mg} / 1$ with water quality standards and water pollution control namely $0.06 \mathrm{mg} / 1$. It can be said that Nitratea levels in the waters of the old Kenjeran Beach are not in accordance with the quality standards. The highest nitrate content occurs at station 1, this occurs because of the high activity around Kenjeran Beach both from fishing activities in the form of boat waste, waste from tourists and land-based waste. While the lowest Nitratee levels occur at station 3 , this occurs because the amount of activity at station 3 is still small. According to Djokosetiyanto dkk, (2006) said that oxygen available in these waters is sufficient for the 
conversion of ammonia to Nitratee, but relatively less conversion of Nitratee to nitrate there will be an increase in Nitratee. Nitratee levels from the sea to the coast will be higher due to runoff from the land which brings rich Nitratee from the dissolution of various wastes from the land and fertilizers so that the Nitratee distribution horizontally is higher when approaching the coast. Decrease in Nitratee levels due to the nitrification process. Nitrification is an important chemical reaction. This chemical reaction works in the ammonium oxidation cycle $(\mathrm{NH} 4+)$ is converted to Nitratee (NO2-) by the group Nitrosomonas, then assisted by a group of Nitrobacter where the group of bacteria will convert oxidized Nitratee back to nitrate (Shirmali and Singh, 2001 in Farihah dkk., 2016).

\section{Nitrat}

Nitrates in waters have an influence on water fertility. This is because nitrate is a factor in primary productivity in microorganisms. Determination of Nitrate Level was carried out using a spectrophotometric device. Nitrate in waters is also very related to the convenience of tourism, especially for tourists who do swimming activities because the level of pollution of waters can be seen from the levels of nitrate derived from oxidation by the group Nitrobacter bacteria. The measurement results of the three stations obtained values ranging from $0.8 \mathrm{mg}$ per liter $-0.16 \mathrm{mg}$ per liter with water quality standards of $0.08 \mathrm{mg}$ per liter. These results indicate that the nitrate content in Kenjeran Beach at station 1 is caused by the presence of waste from the boat and domestic waste which contains a lot of nitrates. In addition, according to Djoko Setiyanto (2006) said that adequate oxygen can convert ammonia to nitrate and Nitrate, but it does not occur in the utilization of nitrates by aquatic organisms (eg phytoplankton) so that there is an increase in nitrate.

\section{Results of Calculation of Water Quality Statistical Analysis}

The results obtained in the $t$ test obtained values of 0.152 and 0.101 and 0.393 which showed a value of $>0.05$, which means there is no difference between station 1 , station 2 and stasin 3 with an error rate of 5\%. This is because of the 9 (nine) parameters of water quality values that are not much different from the three stations. According to Nurizzati (2016) said that if the results of the t-test obtained a value of $<0.05$, it can be said that there were significant differences from the relationship between sample 1 and sample 2 at an error rate of $5 \%$.

\section{Results of Measuring Size of Sediment Granules}

According to Dyer (1986) in Purnawan dkk (2012) states that finer-sized sediments will be easier to move compared to coarse size. Subtle sediments will be transported in the form of a suspension dissolved in water. Coarse sediments are transported near the seabed due to the weight and size of the sediment particles. In addition, larger particles will sink faster than small particles.

\section{The result of Land Suitability Index}

Land suitability analysis is used for coastal tourism with the concept of spatial land evaluation. The criteria used in the form of physical parameters by connecting the biological and geomorphological conditions in the area of Kenjeran Lama Beach. Measurement and observation has conducted on the Tourism Conformity Index (IKW) for coastal tourism activities, namely swimming and playing water. IKW is carried out by direct observation of the three stations. Measurements from the three stations were carried out in a quantitative and qualitative manner which was considered to represent the entire old Kenjeran beach. 
Jurnal Pendidikan Geografi:

Kajian, Teori, dan Praktik dalam Bidang Pendidikan dan Ilmu Geografi

Tahun 24, Nomor 1, Jan 2019, Hal 52-66

Table 2. Water Quality Measurement Results

\begin{tabular}{|c|c|c|c|c|c|c|}
\hline \multirow[t]{2}{*}{ Parameter/Weight } & \multicolumn{2}{|c|}{ Station 1} & \multicolumn{2}{|c|}{ Station 2} & \multicolumn{2}{|c|}{ Station 3} \\
\hline & Result & $\begin{array}{l}\text { Total } \\
\text { Score }\end{array}$ & Result & $\begin{array}{l}\text { Total } \\
\text { Score }\end{array}$ & Result & $\begin{array}{l}\text { Total } \\
\text { Score }\end{array}$ \\
\hline 1. Depth Of Water $(\mathrm{m}) / 5$ & 0,82 & 15 & 0,98 & 15 & 0,71 & 15 \\
\hline 2. Beach Type/5 & Black Sand & 5 & Black Sand & 5 & Black Sand & 5 \\
\hline 3. Beach Width $(\mathrm{m}) / 5$ & $11 \mathrm{~m}$ & 10 & $9 \mathrm{~m}$ & 5 & $14 \mathrm{~m}$ & 10 \\
\hline 4. Basic Water Material/4 & Clay & 0 & Clay & 0 & Clay & 0 \\
\hline 5. Current Speed $(\mathrm{m} / \mathrm{d}) / 4$ & $4,4 \mathrm{~cm} /$ detik & 0 & $3,2 \mathrm{~cm} /$ detik & 0 & $3,6 \mathrm{~cm} /$ detik & 0 \\
\hline 6. Beach Slope (o)/4 & $11^{0}$ & 8 & $15^{0}$ & 8 & $13^{0}$ & 8 \\
\hline 7. Water Brightness $(\mathrm{m}) / 4$ & $13,5 \mathrm{~cm}$ & 0 & $17,5 \mathrm{~cm}$ & 0 & $14,5 \mathrm{~cm}$ & 0 \\
\hline 8. Coastal Land Cover/3 & Settlements & 0 & Settlements & 0 & Open Field & 9 \\
\hline 9. Dangerous Biota/3 & None & 9 & None & 9 & None & 9 \\
\hline $\begin{array}{ll}\text { 10. Availability Of Fresh } \\
\text { Water }(\mathrm{km}) / 3\end{array}$ & $37 \mathrm{~m}$ & 9 & $46 \mathrm{~m}$ & 9 & $57 \mathrm{~m}$ & 9 \\
\hline Total & & 56 & Total & 51 & Total & 65 \\
\hline
\end{tabular}

Conformity Index (IKW) for the coastal tourism category.

Remarks: Total Score $=$ Weight $\mathrm{x}$ Score

Score :

1. Depth Of Water $(\mathrm{m})=3$

2. Beach Type $=1$

3. Beach Width $=2$

4. Basic Water Material $=4$

5. Current Speed $(\mathrm{m} / \mathrm{d})=4$

6. $\quad$ Beach Slope $=2$

7. Water Brightness $=4$

8. Coastal Land Cover $=3$

9. Dangerous Biota $=3$

10. Availability Of Fresh Water $=3$

Table 3. Average Value of Suitability Tourist Index

\begin{tabular}{c|c|c}
\hline No & Station & $\begin{array}{c}\text { IKW Value } \\
(\boldsymbol{\%})\end{array}$ \\
\hline 1 & 1 & 46,7 \\
\hline 2 & 2 & 42,5 \\
\hline 3 & 3 & 54,2 \\
\hline \multicolumn{2}{|c|}{ Average } & 47,8 \\
\hline
\end{tabular}

The results of the measurement of the Tourism Suitability Index (IKW) in the old Kenjeran Beach area obtained results of $47.8 \%$ (S3 is said to be Conditionally Appropriate). Corresponding conditionally in this category can be interpreted in this class as having more limiting factors to fulfill. These factors have an impact on reducing satisfaction in tourism activities. This needs to be considered really so that the stability of the ecosystem persists. According to Sukandar dkk (2017) said that the land suitability index of the coastal tourism category in the category of recreation and swimming that is very feasible is in the category S1 (Very suitable) with coastal recreation activities at the level of $88.33 \%$. 
Jurnal Pendidikan Geografi:

Kajian, Teori, dan Praktik dalam Bidang Pendidikan dan Ilmu Geografi

Tahun 24, Nomor 1, Jan 2019, Hal 52-66

\section{The carrying capacity of the tourist area}

The environment has the capacity to accommodate existing human resources. Calculation of carrying capacity is an important factor because remembering that nature has limits in terms of capacity for tourist activities and others. Here are the results of calculation of carrying capacity for the old Kenjeran Beach.

Tablel 4. The Value of Carrying Capacity of the Tourist Area

\begin{tabular}{|c|c|c|}
\hline No & Parameters & Results \\
\hline 1 & $\mathrm{Lp}$ & $43.000 \mathrm{~m}^{2}$ \\
\hline 2 & $\mathrm{Lt}$ & $50 \mathrm{~m}^{2}$ \\
\hline 3 & $\mathrm{Wt}$ & 9 Clock \\
\hline 4 & $\mathrm{Wp}$ & 3 Clock \\
\hline 5 & $\mathrm{~K}$ & 1 People \\
\hline 6 & DDK & 2.580 People/day \\
\hline \multicolumn{3}{|c|}{$\begin{array}{l}\text { Remarks } \\
\mathrm{K}=\text { Ecological potential supporting unit area (people); } \\
\mathrm{Lp}=\text { Area }(\mathrm{m} 2) \text { or length of the area }(\mathrm{m}) \text { that can be utilized; } \\
\mathrm{Lt}=\text { Unit area that can be used for certain activities }\left(\mathrm{m}^{2}\right) \text { or } \mathrm{m} \\
\mathrm{Wt}=\text { Time provided by the area for tourism activities in one day (hours) } \\
\mathrm{Wp}=\text { Time spent by visitors for any particular activity (hours) } \\
\mathrm{DDK}=\mathrm{K}^{*}(\mathrm{Lp} / \mathrm{Lt})^{*}(\mathrm{Wt} / \mathrm{Wp})\end{array}$} \\
\hline
\end{tabular}

Based on the calculation of the Carrying Capacity of the Regions in the old Kenjeran Beach, the coastal tourism category can support recreational activities and swim with an acceptable number of visitors without reducing the ability of the old Kenjeran Beach area to reach 2,580 people per day with 30,960 people per year in the coastal recreation tourism category.

\section{Results of criteria for tourist objects and attractions}

The main attraction of an area is that the region has an interest in the interest of tourists who want to visit and carry out tourism activities. The following are the results of the assessment of the object and attraction components namely:

Table 5. Attractive Component Results

\begin{tabular}{llccc}
\hline No & \multicolumn{1}{c}{ Element } & Wight & Value & Weight x Value \\
\hline 1 & $\begin{array}{l}\text { The Uniqueness Of Natural And } \\
\text { Artificial Resource }\end{array}$ & 6 & 30 & 180 \\
\hline 2 & $\begin{array}{l}\text { Many Prominent Natural And } \\
\text { Artificial Resource }\end{array}$ & 6 & 30 & 180 \\
\hline 3 & Activities That Can Be Done & 6 & 30 & 180 \\
\hline 4 & Cleanliness Of Tourist Sites & 6 & 15 & 90 \\
\hline 5 & Security $\quad 6$ & 10 & 60 \\
\hline 6 & Convenience & 6 & 30 & 180 \\
\hline & Total Score & & 145 & 870 \\
\hline
\end{tabular}

The results of the assessment according to table 5 obtained a total score of 870 , the score was obtained from the results of multiplication between the weights and the values obtained in each of these elements. The prominent element of uniqueness of natural and artificial resources can be done by knowing the elements of comfort so that a score of 30 is obtained. This value has the meaning that the region can be fulfilled as an attraction of tourist 
Jurnal Pendidikan Geografi:

Kajian, Teori, dan Praktik dalam Bidang Pendidikan dan Ilmu Geografi

Tahun 24, Nomor 1, Jan 2019, Hal 52-66

attractions. The element of cleanliness in a tourist attraction has obtained a value of 15 . This value means that the value of cleanliness affects the location of a tourist attraction. The cleanliness value comes from slum settlements, scattered rubbish and is often found along the surrounding attractions of old Kenjeran Beach. Other pollution problems in the form of nitrate and Nitratee content in water quality in the old Kenjeran Beach tourist attraction which is thought to cause a source of disease for tourists.

Table 6. The Results of Accessibility Components

\begin{tabular}{llccc}
\hline No & \multicolumn{1}{c}{ Element } & Weight & Value & Weight x Value \\
\hline 1 & Road Conditions & 5 & 30 & 150 \\
\hline 2 & Road Type & 5 & 30 & 150 \\
\hline 3 & $\begin{array}{l}\text { Distance From The City } \\
\text { Center }\end{array}$ & 5 & 30 & 150 \\
\hline 4 & $\begin{array}{l}\text { Travel Time From The } \\
\text { Center }\end{array}$ & 5 & 30 & 150 \\
\hline$\quad$ Total Score & & 120 & 600 \\
\hline
\end{tabular}

The results obtained from the assessment of accessibility as shown in table 8 show the value of 30 with each element with the respective weight of 5 . The results of multiplication between weights and values have obtained by the amount of 600 . Based on the results of the assessment the results that the tourist attraction of old Kenjeran Beach has road conditions which are very good. The type of road to the tourist area is paved with a width of 3 meters. The distance from the city center to the old tourist attraction of Kenjeran Beach located in the center of the city in the eastern part of Surabaya is approximately 1hour drive.

Table 7. The results of Accomodation Components

\begin{tabular}{clccc}
\hline No & element/ Sub Element & Weight & Value & Weight $\mathbf{x}$ Value \\
\hline 1 & Total Of Accommodations & 3 & 10 & 30 \\
\hline 2 & Total Of Rooms & 3 & 10 & 30 \\
\hline \multicolumn{2}{c}{ Total Score } & & 20 & 60 \\
\hline
\end{tabular}

The results of the assessment of accommodation components in table 9 show the value of 10 with each element having their respective weights 3 . The results of multiplication between weights and values have obtained by the amount of 60 . The results show that accommodation in the form of lodging and number of rooms in the tourist attraction of old Kenjeran Beach no lodging and rooms to stay so that if tourists who want to stay must get out of the old Kenjeran Beach tourist attraction to the center of Surabaya City or the closest to the old Kenjeran Beach.

Table 8. Results of Facility and Infrastructure Components

\begin{tabular}{llccc}
\hline No & Element/ Sub Element & Weight & Value & Weight x Value \\
\hline 1 & Infrastructure & 3 & 50 & 150 \\
\hline 2 & Means & 3 & 50 & 150 \\
& & & 100 & 300 \\
\hline & Total Score & & \\
\hline
\end{tabular}

The results obtained from the assessment of accessibility in table 8 show the value of 50 with each element having its own weight 3 . The results of multiplication between 
Jurnal Pendidikan Geografi:

Kajian, Teori, dan Praktik dalam Bidang Pendidikan dan Ilmu Geografi

Tahun 24, Nomor 1, Jan 2019, Hal 52-66

weights and values have obtained by an amount of 300. Evaluation of infrastructure as the main support in the area of Kenjeran Beach is a telephone, postal network health, docks, rest areas, playgrounds, gazebos, toilets, mosques, parking lots, information centers, availability of clean water so as to obtain a value of 50. In the facilities as a means to achieve the purpose and objectives in the tourist area, old kenjeran beach is a food vendor and drinks (warungs), centers for food products, souvenir shops from fishery products, public transportation, music entertainment so that they get a value of 50. Infrastructure and facilities around Kenjeran Beach attractions based on the results of observations in the field is still relatively small, one of which is a place to rest, so expect the government, especially the tourism department to provide additional facilities within the area.

\begin{tabular}{|c|c|c|c|c|c|c|}
\hline Variable & $\begin{array}{c}\text { Max } \\
\text { Score }\end{array}$ & $\begin{array}{c}\text { Min } \\
\text { Score }\end{array}$ & $\begin{array}{c}\text { Interval (Max } \\
\text { Score - Min } \\
\text { Score/3) } \\
\end{array}$ & Eligibility Criteria & $\begin{array}{l}\text { Total } \\
\text { Score }\end{array}$ & Ket \\
\hline Attractiveness & 1080 & 360 & 240 & $\begin{array}{c}\text { Worthy }=840-1080 \\
\text { Less Feasible }=600-840 \\
\text { Not Feassible }=<600\end{array}$ & 870 & Worthy \\
\hline Accessibility & 600 & 300 & 100 & $\begin{array}{c}\text { Worthy }=500-600 \\
\text { Less Feasible }=400-500 \\
\text { Not Feassible }=<400\end{array}$ & 600 & Worthy \\
\hline Accommodation & 180 & 60 & 40 & $\begin{array}{c}\text { Worthy }=140-180 \\
\text { Less Feasible }=100-140 \\
\text { Not Feassible }=<100\end{array}$ & 60 & $\begin{array}{c}\text { Not } \\
\text { Feassible }\end{array}$ \\
\hline $\begin{array}{l}\text { Facilities and } \\
\text { infrastructure }\end{array}$ & 300 & 60 & 80 & $\begin{array}{c}\text { Worthy }=220-300 \\
\text { Less Feasible }=140-220 \\
\text { Not Feassible }=<140\end{array}$ & 300 & Worthy \\
\hline \multicolumn{5}{|c|}{ Total } & \multicolumn{2}{|c|}{1830} \\
\hline \multicolumn{5}{|c|}{ Average Total ( Total Score/ Variable (4)) } & \multicolumn{2}{|c|}{457} \\
\hline
\end{tabular}

Table 10. Classification of Object and Tourist Attraction Assessments

\begin{tabular}{ccc}
\hline No & Total Value & Evaluation Based On Element \\
\hline 1 & $399-528$ & Potential to be developed (A) \\
\hline 2 & $308-399$ & Enough potential to be developed (B) \\
\hline 3 & $153-308$ & Not potential developed (C) \\
\hline
\end{tabular}

Based on the average results obtained from a total score of 1830 divided by the number of variables as many as 4 , a value of 457 was obtained. The results stated that the assessment of potential elements is in group A, which has the potential to be developed so that the old Kenjeran Beach can be said to be developed.

\section{Perception Results on Coastal Tourism}

\section{Local Community}

The low level of education of the community around the old Kenjeran Beach makes some communities, especially young people, to build and create their own jobs. Responses from the public regarding the carrying capacity of kenjeran beaches as much as $39.7 \%$ stated that they were very supportive, $26.6 \%$ said they were quite supportive, $33.7 \%$ stated they were not supportive, and $0 \%$ stated they did not support. 
Jurnal Pendidikan Geografi:

Kajian, Teori, dan Praktik dalam Bidang Pendidikan dan Ilmu Geografi

Tahun 24, Nomor 1, Jan 2019, Hal 52-66

\section{Calculation Results of Community Socio-Economic Statistical Analysis}

Statistical analysis using the correlation regression analysis method is the relationship between the independent and bound variables. Analysis of local societies based on socio-economics has variables that are tied to improving the economy of the surrounding community.

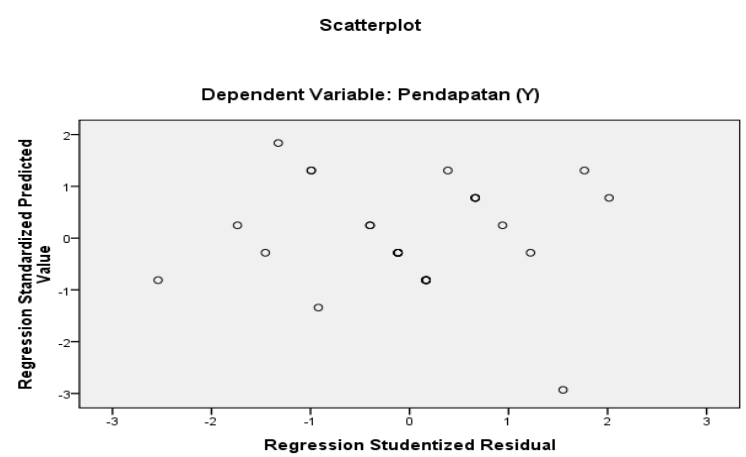

Figure 3. Heteroscedastisity Test

The Heteroscedasticity test shows points that spread randomly and clearly formless patterns. This can be concluded to identify Heteroscedasticity does not occur in the regression model, so the model used in this regression is feasible to use with the aim of predicting socioeconomic variables.

\section{Visitors or Travelers}

Based on interviews with visitors or tourists on the old Kenjeran Beach tour, it was shown that as many as $75 \%$ stated that they were very supportive, $25 \%$ said they were supportive, $0 \%$ stated they did not support. Based on the carrying capacity of the region, $65 \%$ stated that the old Kenjeran Beach was suitable, $35 \%$ said it was quite appropriate and $0 \%$ said it was inappropriate.

\section{Government}

The results of interviews with the Kenjeran Beach Manager Manager about the programs that have been carried out from the government for the old Kenjeran Beach are: a) construction activities such as stage docks which hold concerts and orchestras every Saturday and Sunday; b) beach dock; c) dancing fountains on Saturdays; d) mutual cooperation activities that are held every Friday including the procurement of competitions. This is done to create an attraction for tourists.

\section{CONCLUSION}

Based on the research that has been done at the old Kenjeran Beach Research, conclusions are obtained as follows:

1) Land suitability in the old Kenjeran Beach is obtained from the tourism suitability index (IKW) for coastal tourism in the category of recreation and coastal tourism with a yield of $46.3 \%$ by entering the conditional (S3) class.

2) The old Kenjeran Beach has a carrying capacity for coastal recreation activities with 2,236 people per day with a time limit provided by the manager for 8 hours with an area of old Kenjeran Beach 43,000 Ha and a coastal recreation area of $50 \mathrm{~m}^{2}$.

\section{REFERENCES}


Jurnal Pendidikan Geografi:

Kajian, Teori, dan Praktik dalam Bidang Pendidikan dan Ilmu Geografi

Tahun 24, Nomor 1, Jan 2019, Hal 52-66

Abdillah, D. (2016) Pengembangan wisata bahari di Pesisir Pantai Teluk Lampung. Jurnal Destinasi Kepariwisataan Indonesia. Penelitian dan Pengembangan Kebijakan Kepariwisataan Kementerian Pariwisata. Vol. 1 No. 1 Juni 2016. halaman: 45 - 66.

Arief, D. (1984). Pengukuran salinitas air laut dan peranannya dalam ilmu kelautan. Jurnal Oseana. Pusat Penelitian Oseanografi, Lembaga Oseanologi Nasioanal - LIPI, Jakarta. Volume IX, No. 1: 3-10, 1984.

Djokosetiyanto D, A Sunarma, Widanarni. (2006). Changes of ammonia, nitrite and nitrate at recirculation system of red tilapia (oreochromis sp.) rearing. Jurnal Akuakultur Indonesia. Departemen Budidaya Perairan, Fakultas Perikanan dan Ilmu Kelautan, Institut Pertanian Bogor. 5(1): 13-20 (2006).

Farihah, Rizqi Ayu, Lilik Maslukah, Sri Yulina Wulandari. (2016). Sebaran horizontal konsentrasi nitrat dan nitrate pada kondisi pasang surut di Perairan Cilauteureun, Garut. Jurnal Oseanografi. Jurusan Oseanografi, Fakultas Perikanan dan Ilmu Kelautan, Universitas Diponegoro. Semarang. Volume 5, Nomor 3, Tahun 2016, Halaman $378-389$.

Guntur, Adi Tiya Yanuar, Syarifah Hikmah Julinda Sari, Andi Kurniawan. (2017). Analisis kualitas perairan berdasarkan metode indeks pencemaran di Pesisir Timur Kota Surabaya. Jurnal Ilmu - Ilmu Perairan, Pesisir dan Perikanan. Fakultas Perikanan dan Ilmu Kelautan, Universitas Brawijaya, Malang. P-ISSN: 2089-7790 e-ISSN:25026194.

Nalim. (2015). Analisis komparatif dan eksploratif terhadap kualitas pelayanan bank syariah dan bank konvensional di Kota Pekalongan. Jurnal Hukum Islam. Jurusan Syariah dan Ekonomi Islam. STAIN Pekalongan. Volume 13 Nomor 2, Desember 2015 Halaman $108-118$.

Nugroho Yusuf S, Sasongko P. Hadi, T. Haryono. (2009). Penggunaan software spss untuk analisis faktor daya beli listrik pada sektor rumah tangga dengan metode regresi linier berganda (Studi kasus Kota Salatiga). Jurnal Simposium Nasional. Jurusan Teknik Informatika. Fakultas Komunikasi dan Informatika. Universitas Muhammadiyah Surakarta. ISSN 1412 - 9612.

Nurizzati, Yetti. (2016). Efektivitas pembelajaran statistik dasar dengan metode pratikum berbasis pendidikan karakteristik islami di Jurusan Tadris Ilmu Pengetahuan Sosial IAIN Syekh Nurjati Cirebon. Journal For Islamic Social Sciences. Jurusan Tadris Matematika. Institut Agama Islam Negeri Syekh Nurjati. Cirebon. Vol. 1 Edisi 1. ISSN: 2527-7588.

Purnawan Syahrul, Ichsan Setiawan, Marwatim. (2012). Studi sebaran sedimen berdasarkan ukuran butir di Perairan Kuala Gigieng, Kabupaten Aceh Besar, Provinsi Aceh. Jurnal ilmu-ilmu perairan, pesisir, perikanan. Depik, 1(1): 31-36. April 2012. ISSN 2089 7790.

Sukandar, Citra Satrya Utama Dewi, Muliawati Handayani. (2017). Analisis kesesuaian lahan dan daya dukung lingkungan bagi pengembangan wisata bahari di Pulau Bawean, Kabupaten Gresik, Provinsi Jawa Timur. Jurnal Ilmu - Ilmu Perairan, Pesisir dan Perikanan. Fakultas Perikanan dan Ilmu Kelautan, Universitas Brawijaya. ISSN: 2089-7790, e-ISSN: 2502-6194.

Susana, Tjutju. (2009). Tingkat keasaman $(\mathrm{pH})$ dan oksigen terlarut sebagai indikator kualitas perairan sekitar muara Sungai Cisadane. Jurnal Teknologi Lingkungan. Staf Peneliti, Pusat Penelitian Oseanografi-LIPI, Ancol Timur, Jakarta. Vol. 5, No. 2, Desember 2009, ISSN: 1829-6572 pp. 33-39. 
Jurnal Pendidikan Geografi:

Kajian, Teori, dan Praktik dalam Bidang Pendidikan dan Ilmu Geografi

Tahun 24, Nomor 1, Jan 2019, Hal 52-66

Souhoka Jemmy, Simon I Patty. (2013). Hydrology monitoring in conjunction with the condition of coral reefs in the waters of Talise Island, North Sulawesi. Jurnal Ilmiah Platax. Vol. 1:(3), Mei 2013 ISSN: 2302-3589.

Wijayanto Dian, Dian Minggus Nuriasih, Muhammad Nurul Huda. (2013). strategies of mangrove tourism development in Nusa Penida Marine protected area. Jurnal Saintek Perikanan.Vol. 8, No. 2, 2013:25-32 